\title{
SEGMENTASI REGION OF INTEREST (ROI) GARIS TELAPAK TANGAN MENGGUNAKAN DETEKSI TEPI SOBEL
}

\author{
${ }^{1}$ Khoilil Fitriya, ${ }^{2}$ Hakim,M.Kom \\ 1,2Program Studi Teknik Informatika, Universitas Yudharta Pasuruan \\ ${ }^{1}$ khoilil@gmail.com, ${ }^{2}$ luman@yudharta.ac.id
}

\begin{tabular}{l|l|l} 
Received : April 2019 & Accepted : Mei 2019 & Published : Juni 2019
\end{tabular}

\begin{abstract}
ABSCTRACT
The palm is one of the biometric characteristics that has been relatively recently investigated for identification and verification systems. The reason for using the palm geometry feature is, because the palm geometry is considered more resistant to external factors, such as weather, dry or wet palm conditions compared to using the characteristics of the palm lines that have difficult details and are susceptible to external factors. The problem that often arises in the self-recognition system is that it is easy to commit a crime against a person's identity if only by using something that is owned or something that is known to a system, using biometrics techniques is expected to minimize these frequent problems. Therefore, this study was made to implement the region of interest (ROI) segmentation method for palm line imagery using sobel edge detection, so that it can help for the initial process of identification and verification. the highest accuracy value on the right palm line image reached $87.01 \%$ and the lowest reached $86.46 \%$, the highest accuracy value on the left palm line image reached $85.35 \%$ and the lowest reached $82.68 \%$.
\end{abstract}

Keywords: palm line image, edge detection sobel, segmentation

\section{PENDAHULUAN}

\subsection{Latar Belakang}

Telapak tangan adalah salah satu ciri biometrik yang relatif baru diteliti untuk sistem identifikasi dan verifikasi. Alasan menggunakan ciri geometri telapak tangan adalah, karena geometri telapak tangan dianggap lebih tahan terhadap faktor eksternal, seperti cuaca, kondisi telapak tangan kering atau basah dibandingkan dengan menggunakan ciri garis-garis telapak tangan yang memiliki detail yang sulit dan rentan terhadap faktor eksternal.

Telapak tangan memiliki beberapa kelebihan dibandingkan dengan biometrika lainnya, yaitu dapat menggunakan citra resolusi rendah, biaya alat akusisi relatif rendah, sulit dipalsu, dan bersifat unik dan stabil (Satria Bagus Pamungkas, 2013).

Permasalahan yang sering muncul dalam sistem pengenalan diri adalah mudahnya melakukan tindak kejahatan terhadap identitas seseorang jika hanya dengan menggunakan sesuatu yang dimiliki atau sesuatu yang diketahui pada sebuah system. Oleh karena itu dengan menggunakan teknik biometrika diharapkan dapat meminimalisir permasalahan yang sering terjadi tersebut.

(Intan Purnama Sari \& T. Sutojo, 2016) Dengan judul system identifikasi telapak tangan menggunakan ekstraksi ciri berbasis dimensi fraktal. Dalam penelitian ini digunakan ekstraksi ciri berbasis dimensi fractal dengan metode Box-Counting, sedangkan untuk pencocokkan ciri data acuan dengan data uji telapak tangan digunakan Koefisien Korelasi. Dalam penelitian ini juga didapatkan kesimpulan berdasarkan hasil pengujian data uji, program dapat melakukan diagnosis dengan benar terhadap data yang masuk dengan persentase keberhasilan sebesar 83,33\%.

Berdasarkan fakta diatas, maka segmentasi region of interest (ROI) garis telapak tangan menggunakan deteksi tepi sobel merupakan tahapan awal untuk proses identifikasi agar hasil citra yang didapat lebih baik dan lebih akurat.

Pada penelitian ini dibuat untuk mengimplementasikan metode segmentasi region of interest (ROI) untuk garis telapak tangan, digunakannya deteksi tepi sobel untuk mengetahui batas-batas antara suatu 
obyek dengan latar belakang obyek gambar, sehingga segmentasi ini dapat membantu untuk proses awal identifikasi dan verifikasi.

\subsection{Rumusan Masalah}

Berdasarkan latar belakang masalah yang telah dijelaskan sebelumnya maka dapat disimpulkan rumusan masalah yaitu bagaimana cara untuk mengetahui hasil akurasi metode segmentasi region of interest (ROI) menggunakan metode deteksi tepi sobel jika diterapkan pada citra garis telapak tangan.

1.3 Tujuan Masalah

Adapun tujuan dari penelitiaan ini adalah mencari seberapa akurasi metode segmentasi region of interest (ROI) menggunakan metode deteksi tepi sobel untuk diterapkan pada citra garis telapak tangan.

\subsection{Manfaat Penelitian}

Berdasarkan permasalahan yang diteliti, maka manfaat dari penulisan tugas akhir ini yaitu dihasilkan perangkat lunak deteksi citra garis telapak tangan dengan hasil segmentasi sehingga hasilnya diharapkan bisa membantu untuk proses awal identifikasi dan verifikasi.

\subsection{Batasan Masalah}

Agar tidak menyimpang dari permasalahan, maka penelitian ini mempunyai batasan masalah sebagai berikut :

1. Aplikasi dibangun dengan menggunakan Matlab R2014a.

2. Data citra dalam penelitian ini menggunakan Database CASIA yang diambil dari http://biometrics.idealtest.org/

3. Citra telapak tangan yang digunakan adalah 8 citra telapak kanan dan 8 citra telapak tangan kiri.

\section{TINJAUAN PUSTAKA}

\subsection{Penelitian Terkait}

Pada penelitian sebelumnya telah dilakukan penelitian dengan judul perbandingan metode roberts dan sobel dalam mendeteksi tepi suatu citra, pada penelitian dilakukan pengujian progam yang dilakukan pada beberapa citra masukan dan hasilnya dibandingkan, ternyata metode yang paling baik adalah metode sobel, dikarenakan citra yang diperoleh jelas dan garis tepi yang diperoleh lebih banyak terhubung dibanding dengan metode roberts yang masih putus-putus. Dengan menggunakan metode sobel, masih banyak tepi yang bisa terbaca dibanding dengan metode roberts. Selain itu, deteksi tepi dengan menggunakan metode sobel menghasilkan jumlah pixel warna putih paling banyak. Metode sobel lebih baik dibanding metode roberts karena operator dan ukuran kernel yang digunakan berbeda. Metode roberts lebih menekankan perhitungan gradien arah diagonal, sedangkan sobel lebih ke arah vertikal dan horizontalnya (Lia Amelia, Rini Marwati, 2013).

Pada penelitian sebelumnya telah dilakukan analisis dengan judul "Application of Digital Image Processing and Analysis in Healthcare Based on Medical Palmistry" dalam International Conference on Intelligent Systems and Data Processing (ICISD) menyajikan memperkenalkan sebuah aplikasi pengolahan citra digital dan teknik analisis dalam bidang kesehatan untuk memprediksi beberapa penyakit utama untuk manusia. Aplikasi tersebut menggunakan sistem pengolahan citra, yang bekerja atas dasar palmistry medis sebagai masukan dan diolah serta dianalisa dan menghasilkan prediksi kemungkinan penyakit yang diderita pasien (Hardik Pandit and Dr. D M Shah, 2011).

\subsection{Landasan Teori}

\subsubsection{Telapak Tangan}

Telapak tangan merupakan salah satu biometrika yang memiliki karakteristik unik berupa garis-garis utama pada telapak tangan dan bersifat stabil. Telapak tangan memiliki karakteristik unik yang sangat menjanjikan untuk digunakan, Karakterisitik tersebut diantaranya : ciri geometrik, ciri garis-garis utama, ciri garis-garis kusut atau lemah, ciri titik delta, dan ciri minusi (Ketut Gede Darma Putra, 2009). 


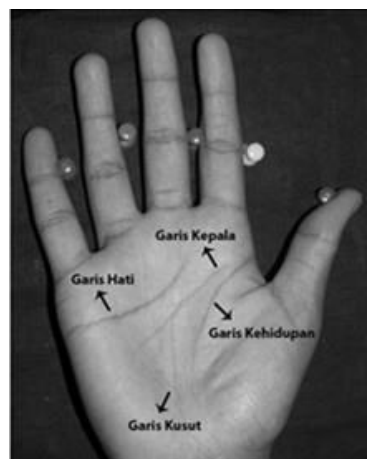

\subsubsection{Grayscale}

Gambar 2.1 : Ciri Garis Telapak Tangan

Citra jenis ini terdiri atas warna abu-abu, bervariasi pada warna hitam pada bagian intensitas terlemah dan warna putih pada intensitas terkuat (Intan Purnama Sari \& T. Sutojo, 2016). Citra grayscale setiap pikselnya merupakan piksel tunggal yaitu informasi intensitas. Citra warna dapat diubah menjadi citra grayscale dengaan cara menghitung rata-rata elemen warna merah, hijau, dan biru sebagai berikut :

$$
\text { grayscale }=\frac{R+G+B}{3}
$$

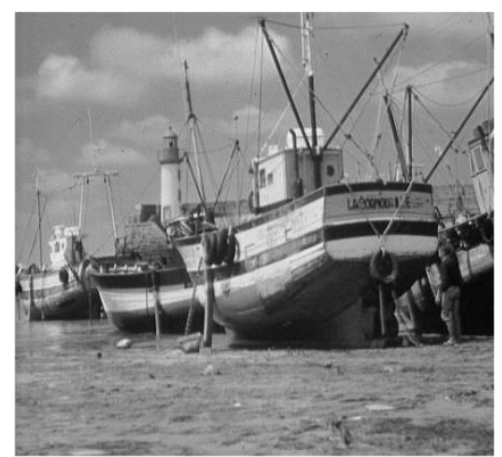

\subsubsection{Deteksi Tepi Sobel}

Gambar 2.3 Citra Grayscale (Intan Purnama Sari \& T. Sutojo, 2016)

Sobel merupakan salah satu pengembangan dari teknik edge detection sebelumnya (Metode Robert) dengan menggunakan HPF ( High Pass Filter) yang diberi satu angka nol penyangga (Yunus, n.d.), juga pengembangan dari operator Prewit. Algoritma ini termasuk algoritma pemrograman yang berfungsi sebagai filter image. Filter ini mendeteksi keseluruhan edge yang ada. Dalam prosesnya filter ini menggunakan sebuah operator, yang dinamakan operator sobel. Metode Sobel merupakan metode yang menggunakan dua buah kernel yang berukuran $3 \times 3$ piksel untuk penghitungan gradient sehingga perkiraan gradient berada tepat di tengah jendela (Lia Amelia, Rini Marwati, 2013). Matrik seperti ini digunakan untuk mendapatkan piksel tengah sehingga menjadi titik tengah matrik. Cara pemanfaatan matrik ini sama seperti pemakaian sebuah grid, yaitu dengan cara memasukkan piksel-piksel disekitar yang sedang diperiksa (piksel tengah) ke dalam matrik. Misalkan susunan piksel-piksel di sekitar piksel $(x, y)$ seperti berikut:

\begin{tabular}{|c|c|c|}
\hline$\alpha 0$ & $\alpha 1$ & $\alpha 2$ \\
\hline$\alpha 7$ & $(\mathrm{x}, \mathrm{y})$ & $\alpha 3$ \\
\hline$\alpha 6$ & $\alpha 5$ & $\alpha 4$ \\
\hline
\end{tabular}

Berdasarkan susunan piksel tetangga, besaran gradien yang dihitung menggunakan operator Sobel adalah sebagai berikut : 
$G=\sqrt{S \frac{2}{x}+S \frac{2}{y}}$

Dimana,

$\mathrm{G}=$ besar gradien operator Sobel

$S_{x}=$ gradien Sobel arah horizontal

$S_{y}=$ gradien Sobel arah vertikal

Di mana $G$ adalah besar gradien di titik tengah kernel dan turunan parsia di hitung menggunakan persamaan berikut :

$$
\begin{aligned}
& S_{x}=(\alpha 2+c \alpha 3+\alpha 4)-(\alpha 0+c \alpha 7+\alpha 6) \\
& S_{y}=(\alpha 0+c \alpha 1+\alpha 2)-(\alpha 6+c \alpha 5+\alpha 4)
\end{aligned}
$$

Di mana $c$ adalah konstanta yang bernilai 2. $S_{x}$ dan $S_{y}$ diimplementasikan menjadi kernel berikut :

$S_{x}=$\begin{tabular}{|c|c|c|}
\hline-1 & 0 & 1 \\
\hline-2 & 0 & 2 \\
\hline-1 & 0 & 1 \\
\hline
\end{tabular}$\quad$ Sy $=$\begin{tabular}{|c|c|c|}
\hline 1 & 2 & 1 \\
\hline 0 & 0 & 0 \\
\hline-1 & -2 & -1 \\
\hline
\end{tabular}

Algoritma metode Sobel dalam mendeteksi tepi suatu citra digital adalah sebagai berikut :

- Citra masukan berupa citra grayscale

- Konvolusikan citra grayscale dengan kernel Sobel horizontal

$\left(S_{\mathrm{x}}\right)=\left[\begin{array}{lll}-1 & 0 & 1 \\ -2 & 0 & 2 \\ -1 & 0 & 1\end{array}\right]$ dan kernel Sobel vertikal $\left(S_{\mathrm{y}}\right)=\left[\begin{array}{ccc}1 & 2 & 1 \\ -2 & 0 & 2 \\ -1 & -2 & -1\end{array}\right]$

- Hitung besar gradien dengan rumus $G=\sqrt{S \frac{2}{x}+S \frac{2}{y}}$

\subsubsection{Region Of Interest (ROI)}

- Citra keluaran merupakan hasil dari besar gradien $(\mathrm{G})$

Region of Interest (ROI) adalah tahap lokalisasi area yang diinginkan (I ketut Gede D P, Erdiawan, 2010). ROI memungkinkan dilakukannya pengkodean secara berbeda pada area tertentu dari citra digital, sehingga mempunyai kualitas yang lebih baik dari area sekitarnya (background). Fitur ini menjadi sangat penting, bila terdapat bagian tertentu dari citra digital yang dirasakan lebih penting dari bagian yang lainnya. Piksel memiliki intensitas tertinggi dalam seleksi citra, kemudian piksel dibandingkan dengan piksel tetangga. Perbandingan ada perubahan dalam tingkat intensitas nilai piksel. Semua piksel memiliki bentuk intensitas yang sama dalam region of interest (ROI).

\subsubsection{Evaluasi Kinerja Sistem}

- Kurva Relative Operating Characteristic (ROC)

Untuk mengevaluasi kinerja dari algoritma segmentasi citra iris mata digunakan kurva ROC yang merupakan langkah umum dalam evaluasi algoritma pendeteksian citra iris mata. Kurva ROC diperoleh dengan cara memplotting bagian dari True Positives (TPR True Positif Rate) versus bagian dari false positif (FPR false positive rate). ROC disebut dengan kurva Relative Operating Characteristic karena ROC merupakan perbandingan dari 2 Operating Characteristic (TPR dan FPR) sebagai kriteria perubahan Pada gambar 3.2 pre-requisites untuk mendapatkan kurva ROC. 


\section{JURNAL EXPLORE IT!}

Vol. 11 No. 1 - Juni 2019

p-ISSN 2086-3489 (Print)- e-ISSN 2549-354X (Online)

Avaiable online at

http://jurnal.yudharta.ac.id/v2/index.php/EXPLORE-IT/

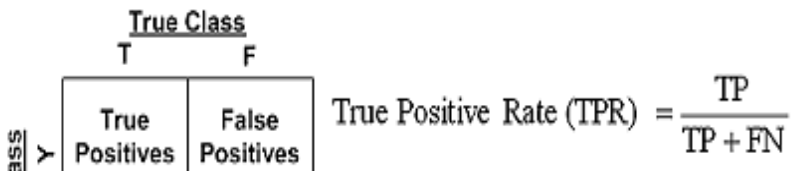

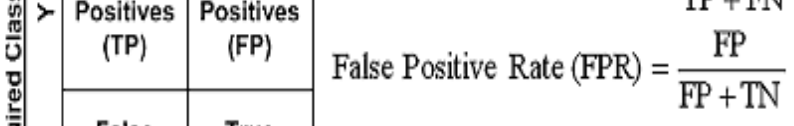

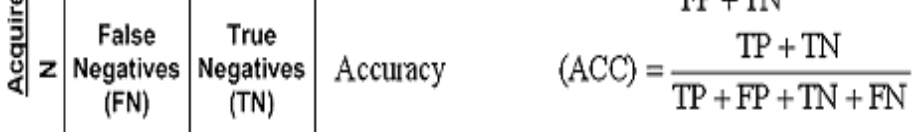

perhitungan ROC

Gambar 2.4 Plotting dan

Gambar kiri, merupakan gabungan matrix. ada 4 pengukuran pada matrix tersebut, yaitu

a. TP adalah jumlah pixel yang diklasifikasikan sistem sebagai bagian iris mata, dan juga diklasifikasikan sebagai citra groundtruth.

b. FP adalah jumlah pixel yang diklasifikasikan sistem sebagai iris mata tapi dikategorikan bukan iris mata pada citra groundtruth.

c. FN adalah jumlah pixel yang diklasifikasikan bukan iris mata, tapi diklasifikasikan sebagai iris mata pada citra groundtruth.

d. TN adalah jumlah total pixel yang diklasifikasikan bukan iris mata. dan juga diklasifikasikan bukan iris mata pada citra groundtruth.

- $\quad$ Area Under Curve (AUC)

Area di bawah kurva ROC (AUC) dalam penelitian ini adalah area di bawah kurva merah pada Gambar. 2.7. Area di bawah kurva ROC (AUC) digunakan untuk membandingkan uji coba

yang berbeda.

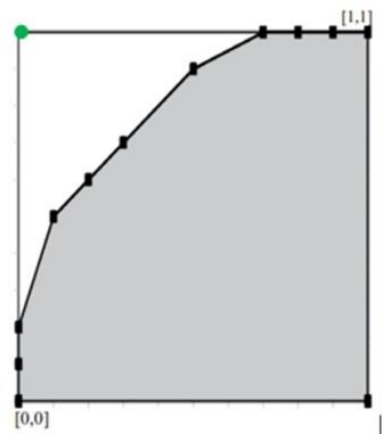

Gambar 2.5 Kurva ROC, plot dari TPR sebagai sumbu y dan FPR sebagai sumbu x

AUC adalah ukuran dari akurasi uji coba.Untuk membandingkan beberapa kurva ROC akan lebih baik jika berupa bilangan skalar.Untuk tujuan tersebut cara yang paling mudah adalah dengan menghitung luas di bawah kurva ROC(Slaby, 2007). Range dari Nilai AUC adalah $0<$ AUC < 1.Jika AUC mendekati nilai 1 maka AUC menunjukkan hasil

3. METODE PENELITIAN uji coba yang sangat baik.

\subsection{Tahap Penelitian}

\subsection{Rancangan Sistem}

Sistem yang dibangun meliputi langkah-langkah ini di jelaskan dalam gambar 3.1. Langkah-langkah tersebut adalah segmentasi region of interest (ROI) garis telapak tangan menggunakan deteksi tepi sobel. 


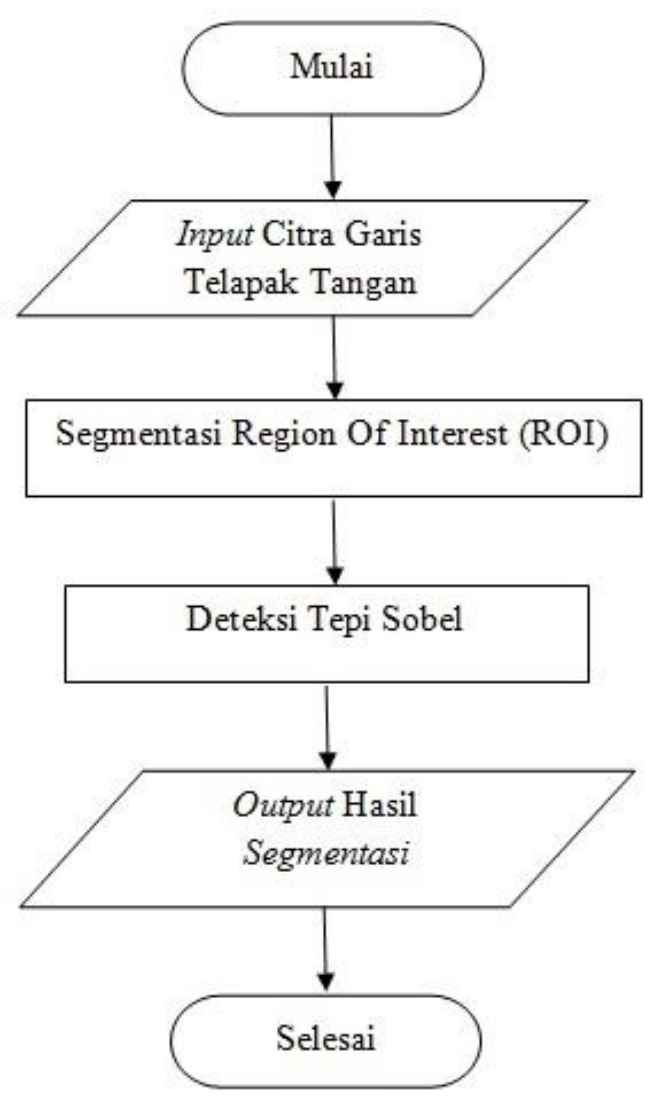

Gambar 3.1 Desain Sistem Secara Umum

Pada gambar 3.1 desain sistem secara umum dijelasakan bahwa pertama kita akan menginputkan citra telapak tangan yang kita ambil dari dataset CASIA. Citra yang diinputkan adalah citra digital, berupa gambar telapak tangan dengan format jpeg $(* j p g)$, citra tersebut berwarna grayscale, sehingga tidak ada lagi citra warna tetapi hanya ada warna keabuan. Proses selanjutnya citra telapak tangan akan di proses segmentasi region of interest untuk menentukan bagian yang dideteksi tepi, pada proses deteksi tepi ini menggunakan metode deteksi tepi sobel.

\subsection{Input Citra}

Pada penelitian ini, data yang digunakan adalah 8 citra garis telapak tangan kanan dan 8 citra garis telapak tangan kiri dari database CASIA yang diambil dari http://biometrics.idealtest.org/. Dalam gambar 3.2 terdapat 3 contoh citra garis telapak tangan kanan dan 3 citra garis telapak tangan kiri dari database CASIA yang disediakan gambar yang diinputkan berukuran 640x480 pixels.

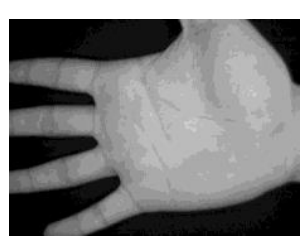

(a) citra telapak kanan

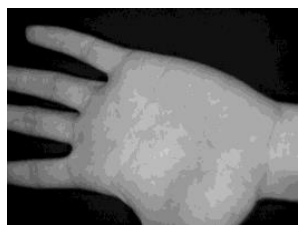

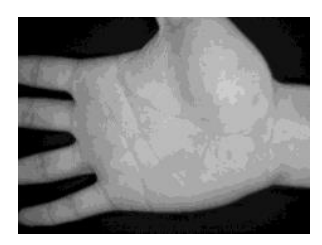

(b) citra telapak kanan

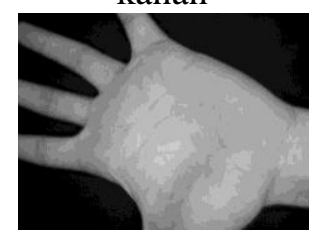

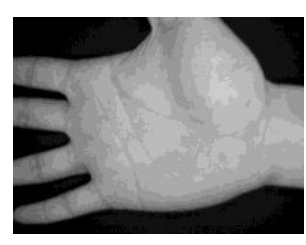

(c) citra telapak kanan

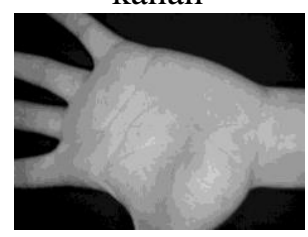



(d) citra telapak
(e) citra telapak
kiri
(f) citra telapak
kiri
kiri

Gambar 3.2 Contoh Gambar Pada Dataset CASIA

\subsection{Segmentasi Region Of Interest (ROI)}

Segmentasi Region of Interest (ROI) adalah tahap lokalisasi area yang diinginkan. ROI memungkinkan dilakukannya pengkodean secara berbeda pada area tertentu dari citra digital, sehingga mempunyai kualitas yang lebih baik dari area sekitarnya (background). Fitur ini menjadi sangat penting, bila terdapat bagian tertentu dari citra digital yang dirasakan lebih penting dari bagian yang lainnya.

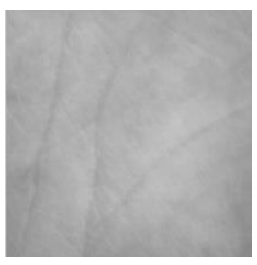

(a) citra telapak kanan

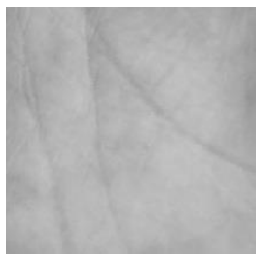

(d) citra telapak kiri

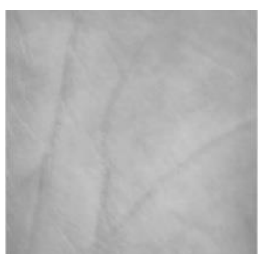

(b) citra telapak kanan

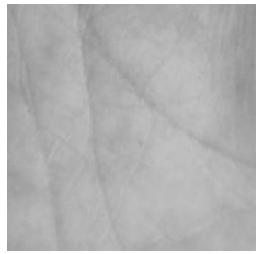

(e) citra telapak kiri

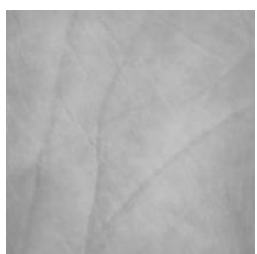

(c) citra telapak kanan

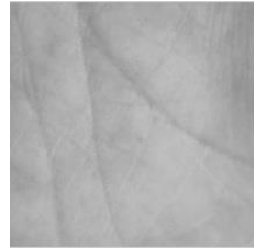

(f) citra telapak kiri

Gambar 3.3 Hasil Citra Segmentasi ROI

\subsection{Deteksi Tepi Sobel}

Deteksi tepi (Edge Detection) pada suatu citra adalah suatu proses yang menghasilkan tepitepi dari suatu objek citra, dan tujuan pendeteksian tepi adalah untuk meningkatkan penampakan garis batas suatu daerah atau objek di dalam citra. Proses deteksi tepi citra dilakukan dengan mencari lokasilokasi intensitas pixel-pixel yang discontinue dengan intensitas pixel-pixel yang berdekatan (bertetanggaan). Suatu titik (x,y) dikatakan sebagai tepi (edge) dari suatu citra, bila titik tersebut mempunyai perbedaan yang tinggi dengan tetangganya.

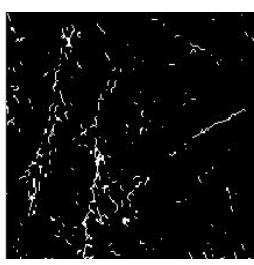

(a) citra telapak kanan

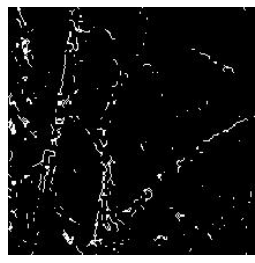

(b) citra telapak kanan

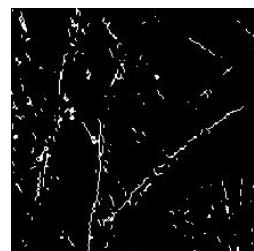

(c) citra telapak kanan 


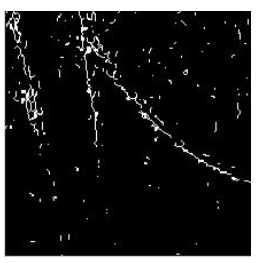

(d) citra telapak kiri

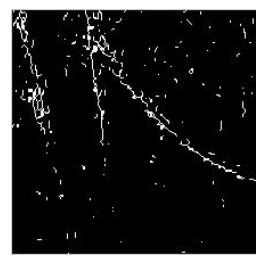

(e) citra telapak kiri

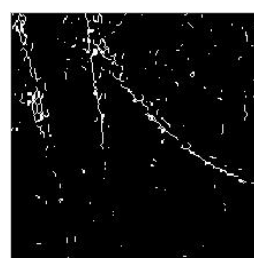

(f) citra telapak kiri

\subsection{Hasil Citra Deteksi Tepi Sobel}

4. HASIL DAN PEMBAHASAN

4.1 Lingkungan Uji Coba

Untuk uji coba pada penelitian ini, spesifikasi dari perangkat keras yang digunakan dalam implementasi perangkat lunak terdiri dari prosesor berjenis Intel dual core, memori berkapasitas 4 GB dan kapasitas harddisk sebesar 500 GB. Sedangkan untuk spesifikasi perangkat lunak yang digunakan dalam implementasi perangkat lunak yakni Microsoft Word 2007, Microsoft Power Point 2007, Microsoft Excel 2007, serta Matlab R2014a.

\subsection{Data Uji Coba}

Pada penelitian ini, data yang digunakan adalah 8 citra telapak tangan kanan dan 8 citra telapak tangan kiri dari database CASIA yang diambil dari http://biometrics.idealtest.org/. Komposisi dalam database ini terdiri dari 8 citra telapak tangan kanan dan 8 citra telapak tangan kiri citra telapak tangan. Masing-masing citra dilengkapi dengan citra groundtruth hasil segmentasi manual Sebagian citra tersebut di sajikan dalam gambar 4.1.

\subsection{Tahap Uji Coba}

Pada tahap ini, akan dilakukan uji coba terhadap system yang tela dikerjakan. Pengukuran kinerja dalam uji coba ini menggunakan akurasi, waktu komputasi dan nilai Area Under Curve (AUC) dari kurva Relative Operating Character (ROC). Kurva ROC adalah kurva yang memetakan antara True Positive Rate (TPR) dan False Positive Rate (FPR) dalam sebuah sumbu koordinat yang didapatkan dari hasil proses segmentasi.

\begin{tabular}{|c|c|c|}
\hline No. & $\begin{array}{c}\text { Citra Asli } \\
\text { Telapak Tangan Kanan }\end{array}$ & $\begin{array}{c}\text { Citra Groundthrud } \\
\text { Telapak Tangan Kanan }\end{array}$ \\
\hline 1. & & \\
\hline
\end{tabular}

\begin{tabular}{|c|c|c|}
\hline No. & $\begin{array}{c}\text { Citra Asli } \\
\text { Telapak Tangan Kiri }\end{array}$ & $\begin{array}{l}\text { Citra Groundthrud } \\
\text { Telapak Tangan Kiri }\end{array}$ \\
\hline 1. & & \\
\hline
\end{tabular}

\subsection{Uji Coba}

\subsubsection{Input Citra}


Pada bagian ini dilakukan ujicoba dengan input citra telapak tangan kanan dan kiri.

\begin{tabular}{|c|c|c|}
\hline No. & $\begin{array}{c}\text { Input Citra } \\
\text { Telapak Tangan Kanan }\end{array}$ & $\begin{array}{c}\text { Input Citra } \\
\text { Telapak Tangan Kiri }\end{array}$ \\
\hline 1. & & \\
\hline
\end{tabular}

\subsubsection{Segmentasi Region Of Interest (ROI)}

Pada tahap Segmentasi Region of Interest (ROI) ini dilakukan tahap lokalisasi area yang diinginkan. Tahap ini menjadi sangat penting, karena terdapat bagian tertentu dari citra digital ini yang lebih penting dari bagian yang lainnya.

\begin{tabular}{|l|c|c|}
\hline No. & $\begin{array}{c}\text { Input Citra } \\
\text { Telapak Tangan Kanan }\end{array}$ & $\begin{array}{c}\text { Segmentasi ROI } \\
\text { Telapak Tangan Kanan }\end{array}$ \\
\hline 1. & & \\
\hline
\end{tabular}

\begin{tabular}{|l|c|c|}
\hline No. & $\begin{array}{c}\text { Input Citra } \\
\text { Telapak Tangan Kiri }\end{array}$ & $\begin{array}{c}\text { Segmentasi ROI } \\
\text { Telapak Tangan Kiri }\end{array}$ \\
\hline 1. & & \\
& & \\
\hline \multicolumn{2}{|c|}{} \\
Gambar 4.5 Input Citra Telapak Tangan Kiri (kiri) dan \\
Segmentasi ROI Citra Telapak Tangan Kiri (kanan)
\end{tabular}

\subsubsection{Deteksi Tepi Sobel}

Pada tahap ini setelah citra telapak tangan melalui proses segmentasi region of interest (ROI) kemudian diproses menggunakan deteksi tepi sobel

\begin{tabular}{|l|c|c|}
\hline No. & $\begin{array}{c}\text { Segmentasi ROI } \\
\text { Telapak Tangan Kanan }\end{array}$ & $\begin{array}{c}\text { Deteksi Tepi Sobel } \\
\text { Telapak Tangan Kanan }\end{array}$ \\
\hline
\end{tabular}




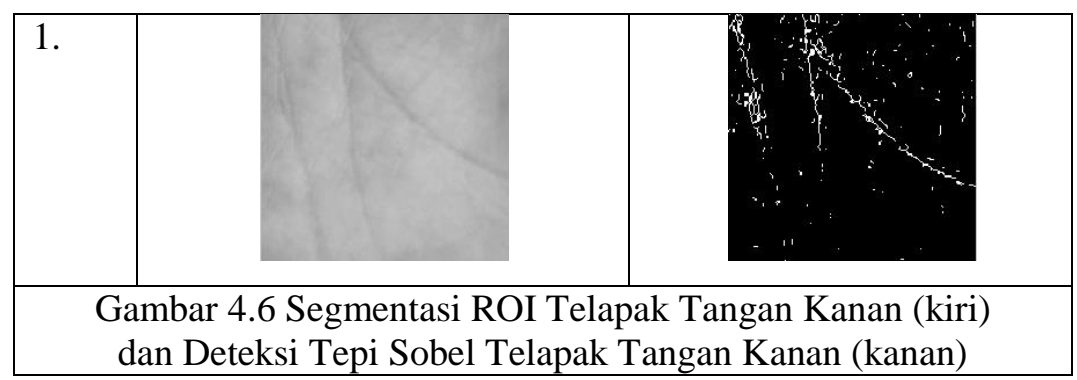

\begin{tabular}{|l|c|c|}
\hline No. & $\begin{array}{c}\text { Segmentasi ROI } \\
\text { Telapak Tangan Kiri }\end{array}$ & $\begin{array}{c}\text { Deteksi Tepi Sobel } \\
\text { Telapak Tangan Kiri }\end{array}$ \\
\hline 1. & & \\
& \\
\multicolumn{2}{|c|}{ Gambar 4.7 Segmentasi ROI Telapak Tangan Kiri (kiri) } \\
dan Deteksi Tepi Sobel Telapak Tangan Kiri (kanan)
\end{tabular}

\subsection{Perhitungan Akurasi Menggunakan ROC}

Dari hasil uji coba mulai input citra pada gambar 4.3 sampai hasil akhir segmentasi pada gambar 4.13. Selanjutnya dilakukan proses perhitungan akurasi menggunakan ROC dimana setelah didapatkan hasil akhir citra segmentasi, kemudian dihitung nilai akurasinya dengan cara membandingkannya dengan citra groundtruth.

\begin{tabular}{|c|c|c|c|}
\hline $\begin{array}{c}\text { No } \\
\text {. }\end{array}$ & $\begin{array}{l}\text { Hasil Segmentasi } \\
\text { Telapak Tangan } \\
\text { Kanan }\end{array}$ & $\begin{array}{l}\text { Citra Groundthrud } \\
\text { Telapak Tangan } \\
\text { Kanan }\end{array}$ & Akurasi \\
\hline 1. & & & 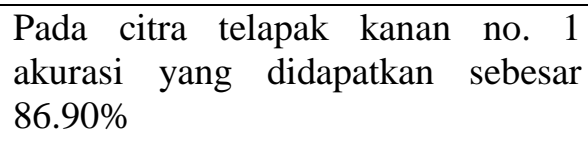 \\
\hline
\end{tabular}

Gambar 4.14 Hasil Segmentasi Telapak Tangan Kanan (kiri) dan Citra Groundthrud Telapak Tangan Kanan (kanan)

\begin{tabular}{|c|c|c|c|}
\hline $\begin{array}{c}\text { No } \\
\cdot\end{array}$ & $\begin{array}{c}\text { Hasil Segmentasi } \\
\text { Telapak Tangan } \\
\text { Kiri }\end{array}$ & $\begin{array}{c}\text { Citra Groundthrud } \\
\text { Telapak Tangan Kiri }\end{array}$ & Akurasi \\
\hline 1. & & & $\begin{array}{c}\text { Pada citra telapak kiri no. 1 akurasi } \\
\text { yang didapatkan sebesar 84.16\% }\end{array}$ \\
& & & \\
\hline
\end{tabular}

Gambar 4.15 Hasil Segmentasi Telapak Tangan Kiri (kiri) dan Citra Groundthrud Telapak Tangan Kiri (kanan)

Hasil akurasi dari uji coba 8 citra telapak tangan kanan dan 8 citra telapak tangan kiri disajikan dalam tabel 4.2 : 
JURNAL EXPLORE IT!

Vol. 11 No. 1 - Juni 2019

p-ISSN 2086-3489 (Print)- e-ISSN 2549-354X (Online)

Avaiable online at

http://jurnal.yudharta.ac.id/v2/index.php/EXPLORE-IT/

Tabel 4.2 Hasil akurasi dari segmentasi yang diusulkan

\begin{tabular}{|c|c|c|c|}
\hline $\begin{array}{c}\text { Citra Telapak } \\
\text { Tangan Kanan }\end{array}$ & ACC (\%) & $\begin{array}{c}\text { Citra Telapak } \\
\text { Tangan Kiri }\end{array}$ & ACC (\%) \\
\hline Citra 1 & 86.90 & Citra 1 & 84.16 \\
\hline Citra 2 & 86.89 & Citra 2 & 84.23 \\
\hline Citra 3 & 86.67 & Citra 3 & 83.52 \\
\hline Citra 4 & 86.46 & Citra 4 & 85.00 \\
\hline Citra 5 & 87.01 & Citra 5 & 82.68 \\
\hline Citra 6 & 86.56 & Citra 6 & 83.54 \\
\hline Citra 7 & 86.78 & Citra 7 & 84.74 \\
\hline Citra 8 & 86.61 & Citra 8 & 85.35 \\
\hline Rata - rata & $\mathbf{8 6 . 7 3}$ & Rata - rata & $\mathbf{8 4 . 1 5}$ \\
\hline
\end{tabular}

\subsection{Pembahasan Hasil Pengujian}

Bagian ini membahas hasil pengujian dari metode yang diusulkan yaitu segmentasi region of interest (ROI) garis telapak tangan menggunakan deteksi tepi sobel. Untuk proses pengujian, hasil berupa akurasi dapat diperhatikan pada Tabel 4.2 nilai akurasi tertinggi pada citra garis telapak tangan kanan mencapai $87.01 \%$ dan terendah mencapai $86.46 \%$, nilai akurasi tertinggi pada citra garis telapak tangan kiri mencapai $85.35 \%$ dan terendah mencapai $82.68 \%$.

\section{PENUTUP}

\subsection{Kesimpulan}

Pada sub-bab ini dipaparkan kesimpulan yang dapat diambil berdasarkan hasil percobaan dan analisa penelitian yang dilakukan terhadap metode yang diusulkan. Kesimpulan tersebut adalah sebagai berikut :

1. Pada proses deteksi tepi telah dilakukan percobaan dengan membandingankan antara deteksi tepi menggunakan metode sobel, canny, prewitt dan robert, hasil dari metode sobel garis pada garis-garis telapak tangan yang telah disegmentasi menyambung, hasil dari percobaan menggunakan metode canny garis nampak tidak beraturan sehingga sulit dibedakan bagian mana yang termasuk garis telapak tangan karena terlalu banyak noise, percobaan metode prewitt masih banyak noise dan garis pada garis telapak tangan nampak putus-putus, pada percobaan deteksi tepi robert noise nampak sedikit namun garis pada garis-garis telapak tangan masih banyak yang terputus. Dapat dibedakan dari percobaan beberapa metode deteksi tersebut bahwa metode deteksi tepi sobel lebih baik.

2. Segmentasi region of interest (ROI) menggunakan deteksi tepi sobel epimampu melakukan segmentasi citra garis telapak tangan dengan baik, yaitu dengan akurasi tertinggi pada citra garis telapak tangan kanan mencapai $87.01 \%$ dan terendah mencapai $86.46 \%$, nilai akurasi tertinggi pada citra garis telapak tangan kiri mencapai $85.35 \%$ dan terendah mencapai $82.68 \%$.

3. Dari uji coba sebanyak 8 citra garis telapak tangan kanan dan 8 citra garis telapak tangan kiri, pada citra garis telapak kanan akurasi terbaik dihasilkan pada citra telapak tangan No.5 mencapai $87.01 \%$ sedangkan akurasi terendah dihasilkan pada citra telapak tangan No.4 mencapai $86.46 \%$. Pada citra garis telapak kiri akurasi terbaik dihasilkan pada citra telapak tangan No.8 mencapai $85.35 \%$ sedangkan akurasi terendah dihasilkan pada citra telapak tangan No.5 mencapai $82.68 \%$.

\subsection{Saran}

Berdasarkan hasil yang didapatkan dari penelitian ini, ada beberapa saran yang berguna untuk penelitian-penelitian mendatang, yaitu :

1. Perlu adanya penambahan metode perbaikan citra untuk mendapatkan akurasi yang lebih baik lagi.

2. Hasil penelitian ini dapat digunakan sebagai bahan acuan atau rujukan untuk penelitian berikutnya.

\section{DAFTAR PUSTAKA}


JURNAL EXPLORE IT!

Vol. 11 No. 1 - Juni 2019

p-ISSN 2086-3489 (Print)- e-ISSN 2549-354X (Online)

Avaiable online at

http://jurnal.yudharta.ac.id/v2/index.php/EXPLORE-IT/

Aditya K Navpat, Rahul Mukherjee, Vishaka Pandita and Sumeet Gupta. (2012). Application of Prediction Software in Palmistry. International Journal of Computer Application - MPGI National Multi Conference .

Ainatul, M., \& Agus, H.,. (2011). Metode Segmentasi Paru-Paru dan Jnatung Pada Citra X-Ray Thorax. 6-8.

Dyah Kusuma Mauliyani, R. Rizal Isnanto, Ajub Ajulian Zahra. (2015). Pengenalan Ciri Garis Utama Telapak Tangan Menggunakan Alihragam Gelombang Singkat Daubechies Dengan Jarak Euclidean. TRANSIENT, VOL.4, NO.3 .

Hambali, Y.A. (2011). Aplikasi Area Prosess Berbasis C\# Menggunakan Visual Studio.

Hardik Pandit and Dr. D M Shah. (2011). Application of Digital Image Processing and Analysis in Healtcare Based on Medical Palmistry. International Journal of Computer Applications .

I ketut Gede D P, Erdiawan. (2010). High Performance Palmprint Identification System Based on Two Dimensional Gabor.

I Made, O. W., dkk. (2015). Preprocessing pada Segmentasi Citra Paru-Paru dan Jantung Menggunakan Anisotropic Diffusion Filter. Teknologi Elektro, 1-2.

Intan Purnama Sari \& T. Sutojo. (2016). Pengenalan Ciri Garis Telapak Tangan Menggunakan Ekstraksi Fitur (GLCM) dan Metode (K-NN).

Kaur, Gurjeet Kaur Seerha Rajneet. (2013). Review on Recent Image Segmentation Techniques. International Journal on Computer Science and Engineering (IJCSE) , 109-112.

Ketut Gede Darma Putra. (2009). Sistem Verifikasi Biometrik Telapak Tangan Dengan Metode Dimensi Fraktal dan Lacunarity.

Lia Amelia, Rini Marwati. (2013). Perbandingan Metode Robert dan Sobel Dalam Mendeteksi Suatu Citra Digital. Jurnal EurekaMatika .

Paolo Sonoge, Andras Koesor and Sandor Pongor. (2008). ROC analysis: applications to the classification of biological sequences and 3D structures. Briefing In Bionformatiocs .

Satria Bagus Pamungkas. (2013). Jaringan Syaraf Tiruan Pada Biometrika Deteksi Citra Garis Telapak Tangan Dengan Metode Backpropagation.

Sneha M. Ramteke. (2013). Segmentation of Palmprint into Region. International Journal of Computers \& Technology, Volume 4 No. 2 .

Snigdha Mankar, A.A. Bardekar. (2017). Palmprint Detection and Verification Using ROI and MLBP Method. IJISET - International Journal of Innovative Science, Engineering \& Technology, Vol. 4 Issue 5 .

Yusdin G, M.A Jennah, Darsikin, dkk. (2013). Panduan Tugas Akhir (SKRIPSI) dan Artikel Penelitian. FAKULTAS KEGURUAN DAN ILMU PENDIDIKAN UNIVERSITAS TADULAKO. 